\title{
The Effect of Fishbone Diagram on Students' Writing of Analytical Exposition Text
}

\author{
Ardianto $^{1}$, Didin Nuruddin Hidayat ${ }^{2}$ and Ismalianing Eviyuliwati ${ }^{3}$ \\ \{ardianto.aa70@gmail.com¹ ${ }^{1}$,didin.nuruddin@uinjkt.ac.id², ismalianing@uinjkt.ac.id² $\}$ \\ ${ }^{1,2,3}$ UIN Syarif Hidayatullah Jakarta, Indonesia
}

\begin{abstract}
As writing in English is seemed to be highly demanded in schools, this study was conducted to obtain the empirical evidence of the effect of Fishbone Diagram on students' writing of Analytical Exposition Text. The research design in this study was quasi-experimental design with 64 samples of the eleventh-grade students of SMAN 4 Tangerang Selatan. The samples were taken through purposive sampling technique and classified into two classes; experimental and controlled classes. The controlled class was treated with conventional teaching method without using Fishbone Diagram while the experimental class was treated by using Fishbone Diagram as the tool to enhance their writing. The instrument of the data collection was writing tests which were given as pretests and post-tests. The data collected from this study were analysed using t-test in order to identify the significance level of the results. This study resulted that both classes gained their scores in post-test. However, the experimental class has performed more significant improvement than the controlled class. Thus, it can be concluded that Fishbone Diagram had significant effect on students' writing of Analytical Exposition Text at the eleventhgrade of SMA Negeri 4 Tangerang Selatan in Academic Year 2018/2019.
\end{abstract}

Keywords: Writing, Fishbone Diagram, Analytical Exposition Text.

\section{INTRODUCTION}

In Indonesia, writing seems to have a special attention since materials about writing existed in many places in the curriculum. The curriculum demanded the students to have sufficient abilities to produce or write several text types. The goal of learning writing is to enhance students' ability to think critically about social phenomenon and build good literacy. One of them is Analytical Exposition Text which is given to the students at the eleventh grade of senior high school. Based on the English syllabus of eleventh grade in 2013 curriculum, students are required to master Analytical Exposition Text in order to be able to differentiate social function, text structure, and language features of spoken and written Analytical Exposition Text by giving and asking information regarding actual issues with suitable contextual usage [1].

Analytical Exposition Text is different from the other text types which are taught in senior high schools in Indonesia. It requires more complex and creative thinking and reasoning since it deals with ideas that should be based on facts, data, and evidence. Students often feel difficult to understand the construction of the ideas, to produce good ideas, and to find corresponding ideas for their topic. They cannot just bring the ideas instantly, but they have to bring also the facts for supporting it to make it convincing. The ideas in the text also should be arranged and organized systematically. Moreover, the ideas should be logically linked to one 
another. So, it can be said that the process of creating Analytical Exposition Text is more complex and longer than making the other types of the text.

To help students in making mind-mapping concepts, a tool called Fishbone Diagram may be an overcoming solution. It provides several branches to make details to construct the main idea. This kind of diagram is actually used to identify the root cause for an effect or problems in improving quality of a product. It is generally known as "cause and effect diagram" which was developed by Kauro Ishikawa. However, Omachonu stated that Fishbone Diagram can be used also as a guide for discussion [2]. Therefore, there are so many possibilities of using this kind of diagram in writing especially in building a good idea in detail. It may help students to first think about what aspects are going to be written after they decided the topic and the thesis statement. Then, they can start to construct the diagram with details under each aspect. It also may give greater opportunities for the students to explore more ideas and detail about the topic of the writing.

Therefore, the researchers decided to investigate the effectiveness of Fishbone Diagram as a mind mapping technique in teaching writing, especially in writing Analytical Exposition Text. The research is trying to answer the following research problem: "Is there any significant effect of using Fishbone Diagram on students' writing of Analytical Exposition Text?"

\section{THEORETICAL FRAMEWORK}

\subsection{Writing an Exposition Text}

Analytical Exposition Text, also known as expository text, is a text that informs explanation about specific subject which should be supported by facts, data, and evidence in detail. Amer stated that "Expository writing differs from narrative and descriptive writing in that it expresses an idea about a topic and uses supporting details to inform or explain to the reader that the idea is sound" [3]. Expository text is different from argumentative text. While argumentative text provides more personal opinion than facts, expository text give true explanation about a subject based on facts, data, and evidences. Also, expository is definitely different from narrative text. While the narrative text is written to form a story, the expository writing is used to form information books [4]. In this text, the perspectives should be introduced in non-opinionated, and non-argumentative way [5]. So, Analytical Exposition Text idea should not be based on opinion or personal thoughts, but it should be based on scientific facts that may come from books, articles, journal, etc.

The purpose of Analytical Exposition Text, generally, is to analyse the topic and persuade the readers to have same view point with the writer. According to Martin and Rose, an exposition has social purpose which is to persuade readers to the writer's point of view [6]. Analytical Exposition Text also has a purpose to communicate factual information to the readers [7].

Generally, the generic structure of an essay consists of introduction, body, and conclusion. The generic structure of Analytical Exposition Text is simplified into title, introduction, body, and conclusion [8]. In the introduction, the writer often generalizes the topic and then narrows it into specific idea called thesis statement. In the body, the topic is provided and generated into more specific ideas or arguments. Each paragraph has its own idea or argument supported with evidences in detail to convince audience or readers. The paragraphs in the body should be logically linked to one another. In the last paragraph or conclusion, the writer can restate the thesis statement and summarize the ideas. In the last paragraph, the writer should not state any new ideas

\subsection{Fishbone Diagram}

Fishbone Diagram is a tool for analyzing and exploring relation between a cause and an effect or a problem. After placing the problem or effect in the head of the diagram, the causes of the effect can be analyzed and investigated. According to Omachonu and Ross, cause-andeffect diagram is a tool to analyze root cause for a problem and organize the mutual 
relationships [9]. This kind of diagram is also called as 'Fishbone Diagram' because it looks like fish skeleton or bone [10]. Fishbone Diagram was designed, actually, to generate improvement ideas of a product quality with investigating the root cause of a problem. However, as already mentioned, Fishbone Diagram also can be used in educational settings.

This diagram is imagined as bone of a fish which has several branches. Each branch of the bone become each aspect to be analyzed, which probably has a cause to be a problem. The bone can be identified as each measure aspect. Those aspects can be changed to any aspects depending on what kind of problem that needs to be analyzed. Fishbone Diagram can assist the user in gathering and organizing ideas or possible cause of an effect, grasping a common understanding of the problem, analyzing gaps in present knowledge [11].

The main function of Fishbone Diagram is to analyze the root cause of an effect or problem and investigate the relationships. It can determine detailed factors of a cause. It is very useful to evaluate systematically the causes of an effect. It means that Fishbone Diagram can be powerful tool for brainstorming and mind mapping ideas. Ishikawa described several ways to use Fishbone Diagram.

First, Fishbone Diagram actually can be used for educational purposes. It can get many ideas from involved members. Everyone will gain new knowledge as well as there are many people involved in making Fishbone Diagram. Second, Fishbone Diagram can be a guide for discussion. When it is focused for discussion, every member will discover the topic and how far the topic or the discussion has developed. Third, the causes can be found clearly and the results can be written clearly on the diagram. Fourth, Fishbone Diagram can reveal the technology level. When it analyzes the production process, then the level of technology used in the factory can be determined. Fifth, aspects of brainstorming can be combined by Fishbone Diagram systematically in order to make powerful technique [12].

As already mentioned, Fishbone Diagram was used for analysing root cause of a problem in manufacturing industry. Here is the example of Fishbone Diagram adopted from Dale.

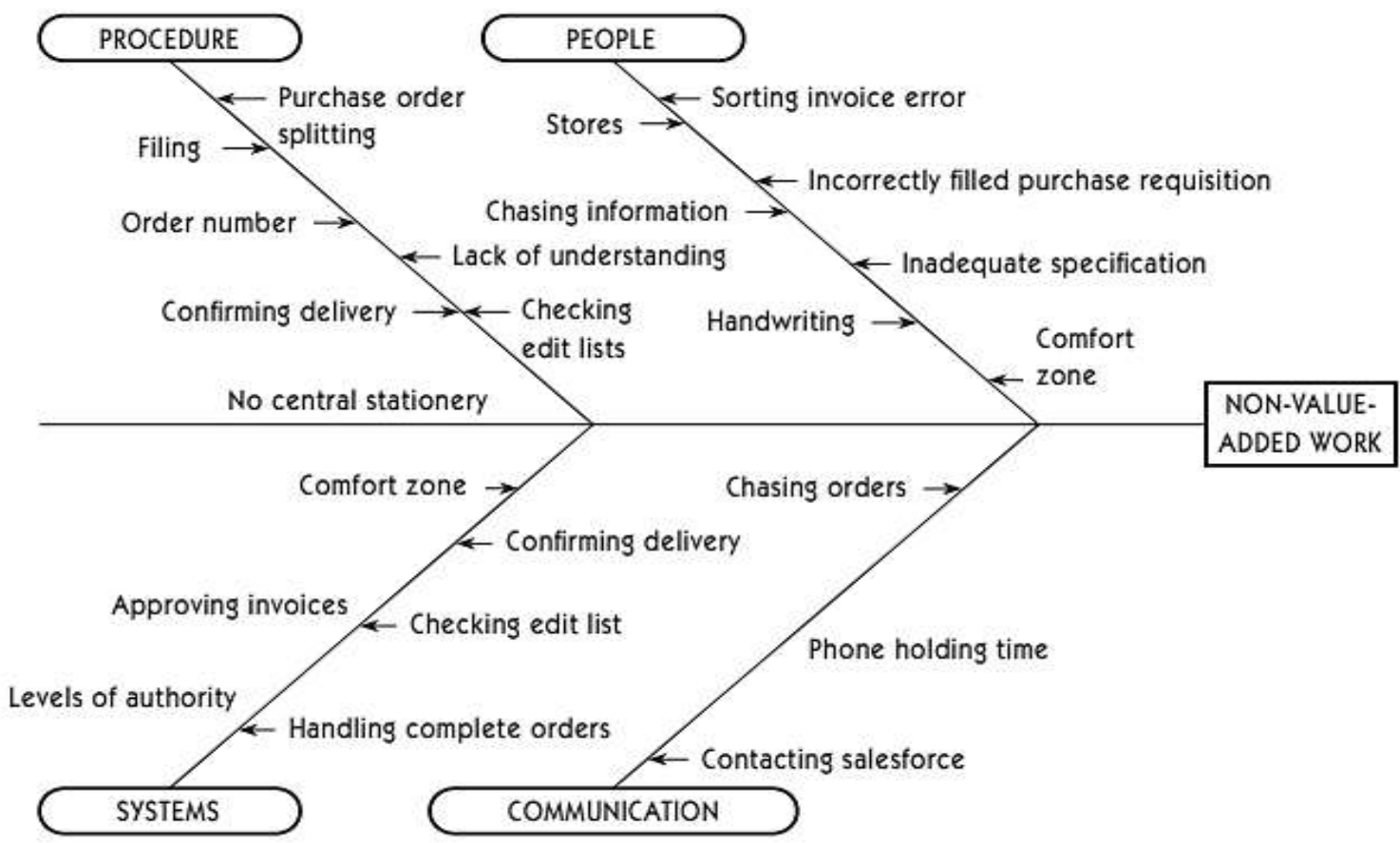

Fig.1. Fishbone Diagram Analysis: purchasing department non-value-added work analysis 
Fishbone Diagram above shows some aspects causing problem for non-value-added work in a purchasing department. The problem was analyzed by creating the Fishbone Diagram in order to investigate the root causes of the problem. The casues of the problem then was analyzed by determining the possible factors or aspects. Each aspect is investigated at what fators influencing the aspect. For example, the first aspect is procedure which has some subcauses that could influence how the procedure is implemented. Each sub-cause then will be analyzed whether it has significant effects to the aspects of procedure and how does the subcause influence the implementation of the procudere will be questioned.

\subsection{Teaching Writing of Analytical Exposition Text by Using Fishbone Diagram}

Since Analytical Exposition Text requires students to think critically about a phenomenon or topic, students need to have good logical reasoning in building ideas to construct the text. The Fishbone Diagram can be used to help students in organizing the ideas into good structured text. It can be said that at least students can get three beneficial advantages. First, it helps students to think rationally and systematically. Second, it can help students to write the text with good ordering of the ideas, because students can directly see the diagram while they are writing the text. In additional, students also can use Fishbone Diagram to understand and analyze the structure of an Analytical Exposition Text.

In writing, Fishbone Diagaram can be used as a mind-mapping tool to help writers to organize and develop ideas in pre-writing process. It simply ilustrates the construction of the ideas in the writing. It also stimulate the user to collect more ideas as long as the contents developed and elaborated.

To simply help the readers to understand the function of each part of the Fishbone Diagram, the researchers adapted a model of Fishbone Diagram when it serves as mindmapping tool in writing.

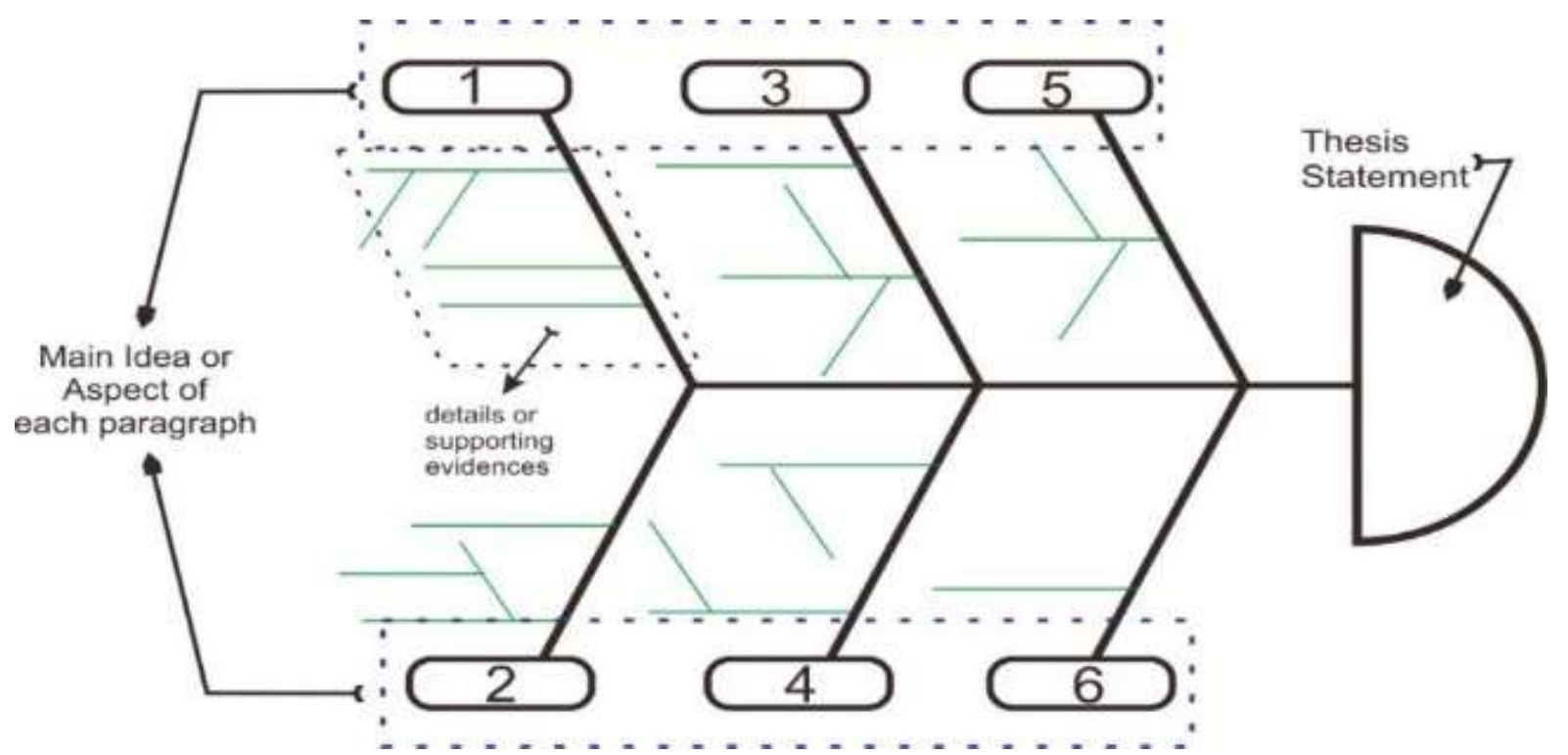

Fig. 2. Adapted Fishbone Diagram for Writing

\subsubsection{Steps to Use Fishbone Diagram}

There are several steps to use Fishbone Diagram in the classroom learning activities:

2.3.1.1 Provide students with a text along with its Fishbone Diagram. Students can identify the pattern or structure used in the text by matching with the structure of the Fishbone Diagram. 
2.3.1.2 After the students understand the works of Fishbone Diagram, provide the students with a new text and an empty Fishbone Diagram. The students can be asked to put the ideas and detail from the text into the Fishbone Diagram as practice.

2.3.1.3 After the Fishbone Diagram have been introduced to the students, they should be ready to produce a text by using the Fishbone Diagram. Provide the students with familiar topics to wirte.

\subsubsection{Procedural Instructions}

Here are procedural instructions of how to use Fishbone Diagram to construct the organization of the ideas:

2.3.2.1 After determining the topic and the thesis statement of the writing, put the thesis statement to the head of the Fishbone Diagram.

2.3.2.2 Students should determine what aspects or areas that are going to be written and explained in the body paragraph. They can put the details, supporting evidence, or example in the root of each aspect.

2.3.2.3 Students can write the conclusion by looking back to the thesis statement or summarizing the ideas.

\subsection{Research Hypotheses}

2.4.1.1 Null Hypothesis $\left(\mathbf{H}_{\mathbf{0}}\right)$ : There is no significant effect of Fishbone Diagram on students' writing of Analytical Exposition Text.

2.4.2 Alternative Hypothesis $\left(\mathbf{H}_{\mathbf{a}}\right)$ : There is significant effect of Fishbone Diagram on students' writing of Analytical Exposition Text.

\section{RESEARCH METHODOLOGY}

It is a quantitative research using quasi-experimental design. The samples of the research were 64 eleventh grade students of SMA Negeri 4 Tangerang Selatan, located at Jl. Yaktapena Raya Pondok Ranji, Ciputat Timur, Tangerang Selatan in the academic year 2018/2019. The samples were divided into one experimental class and one controlled class to see the effect of the given treatment. The experimental class was taught analytical exposition text using Fishbone Diagram, while the controlled class was not given Fishbone Diagram to learn how to create organized analytical exposition text. The pre-tests and post-tests to both classes were as the instruments of data collection to know the improvement of the students' achievement on writing analytical exposition text before and after the teaching processes. The students' writing was then assessed by using Heaton's Rubric for Assessing Writing adopted from Weigle, consisting of some areas, such as content, organization, vocabulary, language use, and mechanics [13].

The data was analyzed and calculated using $t_{\text {test }}$ through SPSS software. It included several steps in the process, such as normality, homogeneity, and hypothesis testing. Normality test was used to determine whether the sample data was normally distributed or not. It was also used to determine whether the sample data were parametric or non-parametric, while the homogeneity test was used to find out whether the sample data from experimental and controlled class were of the same variants. The next step of data analysis process was testing the hypothesis using $t_{\text {test }}$. If the data are of the same variant, then the hypothesis can be tested with $t_{\text {test. }}$. The $\mathrm{t}_{\text {test }}$ is formulated as follow:

Explanation

$$
t_{o}=\frac{M x-M y}{S E M x-M y}
$$

to $\quad=$ The value of ' $t$ ' count

$\mathrm{Mx}=$ Mean variable of experimental class

My $\quad=$ Mean Variable of controlled class

SEM1 = Standard error of experimental class

SEM2 = Standard error of controlled class 
After $t_{\text {test }}$ was conducted, then an effect size calculation was needed in order to determine whether the effect is strong or weak because the significance of the relationship does not determine the strength or weakness of the effect [14]. In this research, to determine whether the effect was strong or weak, the researcher used Cohen's d analysis [15].

After the calculation of effect size was done, the result could be interpreted with following criteria:

$$
\begin{array}{ll}
0-0.20 & =\text { weak effect } \\
0.21-0.50 & =\text { modest effect } \\
0.51-1.00 & =\text { moderate effect } \\
>1.00 & =\text { strong effect }
\end{array}
$$

\subsection{Statistical Hypothesis}

The hypothesis can be proved with following criteria:

3.1.1 If $t_{\text {test }}\left(t_{\mathrm{o}}\right)>\mathrm{t}_{\text {table }}\left(\mathrm{t}_{\mathrm{t}}\right)$ in significance degree 5\%, null hypothesis $\left(\mathrm{H}_{\mathrm{o}}\right)$ is rejected or alternative hypothesis $\left(\mathrm{H}_{\mathrm{a}}\right)$ is accepted.

3.1.2 If $\mathrm{t}_{\text {test }}\left(\mathrm{t}_{\mathrm{o}}\right)<\mathrm{t}_{\text {table }}\left(\mathrm{t}_{\mathrm{t}}\right)$ in significance degree $5 \%$, null hypothesis $\left(\mathrm{H}_{\mathrm{o}}\right)$ is accepted or alternative hypothesis $\left(\mathrm{H}_{\mathrm{a}}\right)$ is rejected.

\section{RESEARCH FINDING AND DISCUSSION}

\subsection{Data Description}

The sample size of 64 students were taken from Class XI IPA 4 as the experimental class (32 students) and from Class XI IPA 1 as the controlled class (32 students). The selection of the experimental class and controlled class was determined by considering previous performance of the students and discussion with their English teacher. Figure 3 and 4 below present the students' writing scores.

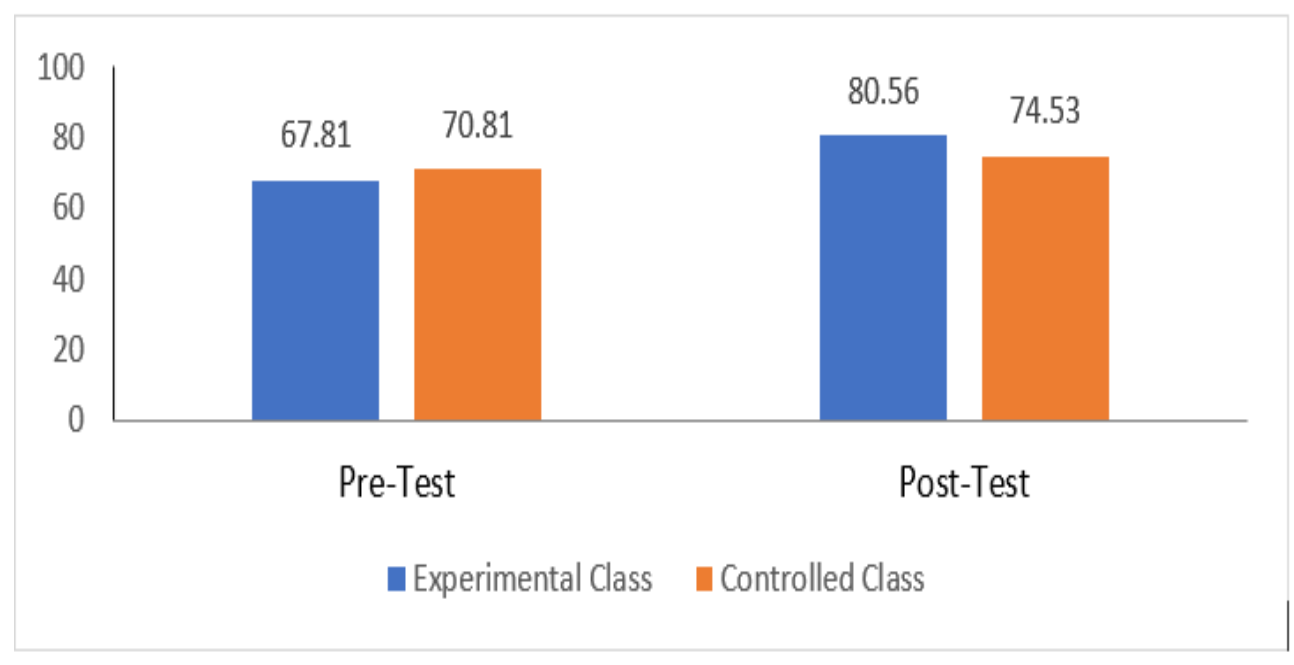

Fig. 3. The Difference between Students' Mean Score in Experimental and Controlled Class 


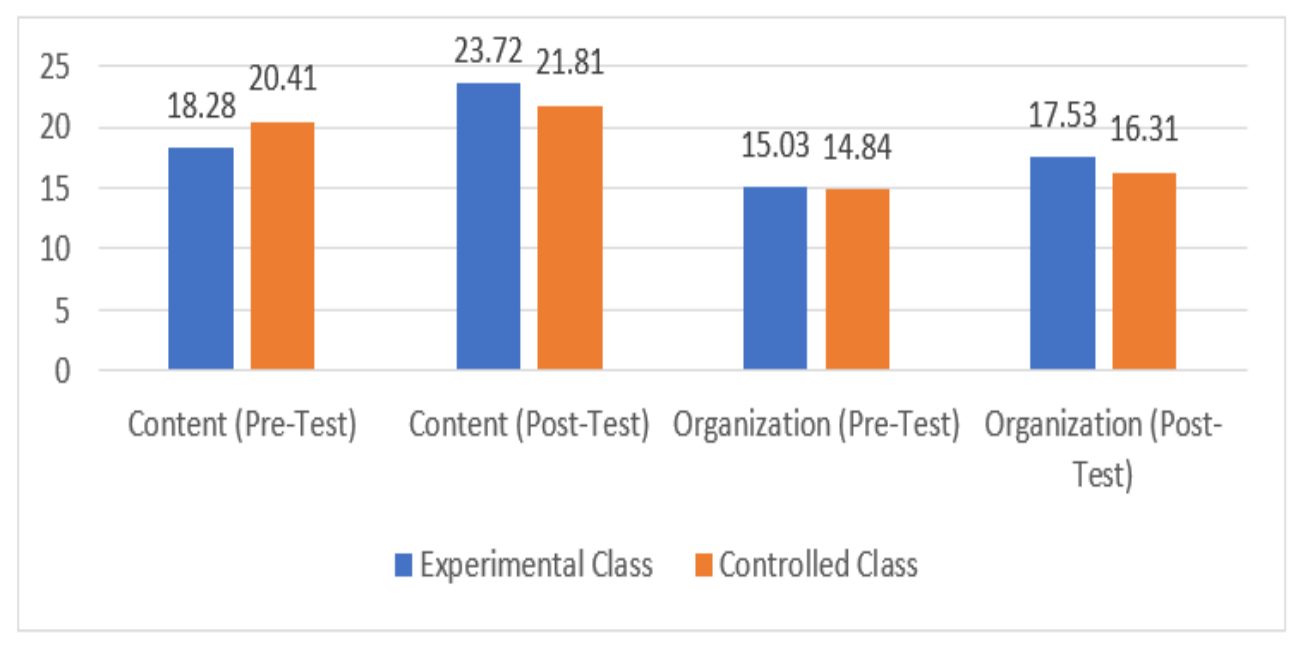

Fig. 4. The Difference between Students' Mean Score of Organization and content aspects in Experimental and Controlled Class

Figure 3 showed that in the pre-test, the mean score of the controlled class (20.41) is higher than that of the experimental class (18.28). However, in the post-test, the mean score of the experimental class (80.56) turns out to be higher than that of the controlled class (74.53). This means that the controlled class performed better in the pre-test. However, the experimental class successfully gained their score and performance in the post-test. This would mean that the Fishbone Diagram has significant roles in enhancing their writing of Analytical Exposition Text.

Based on the figure 4 above, there were two main aspects of writing which are content and organization. The experimental class got the mean score 18.28 for the content in pre-test and they eventually gained the mean score to 23.72 in the post-test. Meanwhile, the controlled class gets the mean score 20.41 for the content in pre-test, and they gained the mean score to 21.81 in post-test. In the content aspect, the gained score of the experimental class was higher than that of the controlled class. In the organization aspect from pre-test result, the mean score of the experimental class was 15.03 and the mean score of controlled class was 14.84 . Meanwhile, in the post-test, the experimental class eventually gained their mean score to 17.53 and the controlled class also gained their mean score to 16.31 . It means that the experimental class also gained more score in the organization than the controlled class. This would mean that the students from experimental class did better organization and content management in their writing after using the Fishbone Diagram. Fishbone Diagram helped the students to organize and collect ideas in depth and detail. To sum up, both the experimental class and controlled class improve their scores of content and organization aspects from the pre-tests to the post-tests, but the gained score of the experimental class was higher than that of the controlled class.

\subsection{Data Analysis}

The data in this study are analyzed using t-test in order to test the hypothesis. Before conducting the t-test, the data are first analyzed using normality and homogeneity test. The normality test is aimed to discover whether the data are normally distributed or not. It was also used to determine whether the sample data are parametric or non-parametric. Homogeneity test is aimed to check whether the data are homogenous or not. The data analysis was conducted by using SPSS Version 24, yet manual calculation was also used to verify the results from SPSS. 


\subsection{Normality Test Result}

The normality test used a significance level $\alpha=0.05$. If the results of significance form Shapiro-Wilk are higher than 0.05 , then the data is normally distributed. The results of normality test of the pre-test in both experimental and controlled classes indicate that the collected data are normally distributed since the significance level of Shapiro-Wilk from those classes is 0.947 from the experimental class and 0.122 from the controlled class. In which they are higher than the significance level $\alpha=0.05$.

The results of normality test on post-test in both experimental and controlled class were also showing that the data were normally distributed. It can be seen from the results of Shapiro-Wilk significance which shows 0.320 as significance level from experimental class and 0.230 as significance level from controlled class. Both results are higher than the significance level $\alpha=0.05$. In conclusion, the data of pre-test and post-test from both classes are normally distributed.

\subsection{Homogeneity Test Result}

This test is aimed to discover that the samples of the data are homogenous or have same distribution of the same variable. The result shows that the significance of Pre-Test is 0.524 which is higher than the significance level $\alpha=0.05$. Meanwhile, the homogeneity test of the post-test shows 0.631 as the significance value of the data. Both result of the pre-test and posttest are higher than the significance level $\alpha=0.05$ which means that the data are homogenous.

\subsection{Hypothesis Testing}

The hypothesis testing is conducted to investigate the existence of significant differences in the results of the post-test between experimental and controlled classes after the treatments are given. This test will determine how significant the effect of the Fishbone Diagram is, used in the treatments, on students' writing of Analytical Exposition Text. This hypothesis testing is done not only by using IBM SPSS version 24 but also by calculating the test manually in order to create reliable support and verification.

The SPSS resulted that $t_{0}=3.466$. In addition, the manual calculation resulted that $t_{0}=3.48$ with degree of freedom $=62$. Therefore, in significance degree of $5 \%$, the $t_{\text {table }}\left(t_{t}\right)=2.000$ was used.

The research hypotheses can be proved with following criteria:

4.5.1 If $\mathrm{t}_{\text {test }}\left(\mathrm{t}_{\mathrm{o}}\right)>\mathrm{t}_{\text {table }}\left(\mathrm{t}_{\mathrm{t}}\right)$ in significance degree $5 \%$, null hypothesis $\left(\mathrm{H}_{\mathrm{o}}\right)$ is rejected or alternative hypothesis $\left(\mathrm{H}_{\mathrm{a}}\right)$ is accepted.

4.5.2 If $\mathrm{t}_{\text {test }}\left(\mathrm{t}_{\mathrm{o}}\right)<\mathrm{t}_{\text {table }}\left(\mathrm{t}_{\mathrm{t}}\right)$ in significance degree $5 \%$, null hypothesis $\left(\mathrm{H}_{\mathrm{o}}\right)$ is accepted or alternative hypothesis $\left(\mathrm{H}_{\mathrm{a}}\right)$ is rejected

The hypothesis then can be interpreted with following formula:

$$
\begin{aligned}
\mathrm{H}_{\mathrm{a}} & =\mathrm{t}_{\mathrm{o}}>\mathrm{t}_{\mathrm{t}} \\
& =3.48>2.000
\end{aligned}
$$

Then, it could be concluded from the calculation above that $\mathrm{H}_{\mathrm{a}}$ is accepted. This means that there is a significant effect of Fishbone Diagram on students' writing of Analytical Exposition Text.

\subsection{Effect size}

The calculation resulted 0.88 as the value of the effect size. Based on Cohen's criteria of measuring the strength of the effect, the result is in between the interval 0.51-1.00. It can be concluded that Fishbone Diagram has moderate effect on students' writing of Analytical Exposition Text. 


\section{DISCUSSION}

Based on the hypothesis testing (3.48) and the calculation of the effect size (0.88), there is a significant effect of Fishbone Diagram on students' writing of Analytical Exposition Text. It is showed by the statistical calculation that the $t_{0}$ is higher than t-table $(3.480>2.000)$, therefore the $H_{a}$ is accepted. Moreover, the effect size calculation put one more emphasis to the result. It showed that the Fishbone Diagram has moderate effect on students' writing of Analytical Exposition Text. It means that the effect is neither strong nor weak. However, it proves that students who are taught Analytical Exposition Text using Fishbone Diagram have better comprehension and show better scores in the post-test. It can be concluded that Fishbone Diagram has a significant effect on students' writing of Analytical Exposition Text.

In the process of data collection, the experimental class has lower mean score in pre-test, which is 67.81 , compared to the pre-test mean score of the controlled class which is 70.81 . It means that the controlled class has better ability in writing the Analytical Exposition Text. Eventually and surprisingly, the experimental class has successfully gained their score significantly in the post-test after given the treatments. The mean score of the post-test of the experimental class is 80.56 which is significantly higher than the mean score of the controlled class in post-test which is 74.53. Both classes show some improvement on their writing but the experimental class showed better improvement.

Fishbone Diagram, as a mind-mapping tool, in this research was acknowledged as an effective way to collect more ideas and thoughts. This is in line with Buzan who states that mind mapping is far more creative and effective to collect ideas rather than using note taking [16]. In pre-writing process, it is easier to follow graphic rather than to follow a note. Fishbone Diagram can be used as a tool for making pre-writing process easier and more organized. It can control the ideas of the topic to be focused in the line. It can be said that Fishbone Diagram can provide simple guidance to follow in the writing process.

The result of this study is also in line with Nadell, Langan, and Comodromos who stated that mind-mapping generate ideas continuously and stimulate the free flow of the ideas [17]. Mind-mapping simply encourage more to collect more ideas related to the topic being discussed. From the result, it can be seen that experimental class gained their content and organization scores in both pre-test and post-test. This also means that Fishbone Diagram helps them to develop their brain to collect more ideas and make the ideas more organized. This study proves that Fishbone Diagram can be used not only for analyzing root cause of a problem, but also for growing up the ideas in the writing.

The finding of this study supports some related theories. This study proves that mindmapping is a good way to be conducted in the writing process. This study focuses on the use of mind-mapping tool called Fishbone Diagram in teaching writing. Writing consists of the pre-writing process which requires the writers to build good construction of the ideas. Therefore, Fishbone Diagram is investigated in order to prove that it is statistically effective to be used as a helping tool for the pre-writing process. From the result, it can be seen that Fishbone Diagram can enhance the quality of the writing in term of structural organization of the ideas. By using Fishbone Diagram, the students can focus more to the discussed topic of the text so the ideas can be maintained well. In addition, the Fishbone Diagram also can help students to organize the order or the sequence of the ideas so the ideas will not be disordered. Although it was not designed specifically for writing, but actually it can be implemented in learning and teaching in the school especially for writing. When the students are involved to the writing process, Fishbone Diagram guides them to write in an organized order of the ideas. In addition, the students are more triggered to learn writing by using Fishbone Diagram.

\section{CONCLUSION}

The aim of this study is to obtain empirical evidence whether Fishbone Diagram has a significant effect on students' writing of analytical exposition text for Eleventh Grade students of SMA Negeri 4 Tangerang Selatan in Academic year 2018/2019. It is also aimed to support 
related previous study in order to provide additional information about teaching writing using a mind-mapping tool.

Since writing was relatively important in the curriculum for high school, the conduction of teaching writing cannot remain ineffective. This study had revealed that Fishbone Diagram can be used as a tool to help students in dealing with writing specially in producing an essay with organized ideas. Based on the finding, Fishbone Diagram has a significant effect on students' writing of analytical exposition text at Eleventh Grade of SMA Negeri 4 Tangerang Selatan. It is also proved by looking at the effect size result $(0.88)$ that Fishbone Diagram has moderate effect on the students' writing. Students who are taught using Fishbone Diagram perform better than those who are not. It is proved by the calculation of hypothesis testing using significance of 5\% (0.05). Alternative hypothesis $\left(\mathrm{H}_{\mathrm{a}}\right)$ is accepted and Null Hypothesis $\left(\mathrm{H}_{0}\right)$ is rejected since $\mathrm{t}_{0}(3.48)$ is higher than the $\mathrm{t}_{\mathrm{t}}(2.000)$.

To conclude, it can be interpreted that there is a significant difference between the results of students' writing of Analytical Exposition Text by using Fishbone Diagram and by not using Fishbone Diagram at the Eleventh-Grade students of SMA Negeri 4 Tangerang Selatan.

\section{SUGGESTION}

From this study, there are several suggestions that may be useful for English teachers or other researchers who are interested in teaching writing of Analytical Exposition Text by using Fishbone Diagram in order to improve their understanding on how to about create wellorganized Analytical Exposition Text.

For students learning English, in order to gain their ability in writing, they can use Fishbone Diagram to help them building structured ideas of the writing. They also can learn how to analyze the organization of the ideas in an essay by using Fishbone Diagram. In addition, they should have more comprehension in building ideas starting from general statement to specific or detailed information supporting the general statement. Moreover, the students should encourage themselves to be more familiar with written English language by practicing more learning activities such as reading, writing, listening, speaking, discussing, etc.

For institutions related to teaching and learning English, students should be provided with more relevant facilities related to English language learning such as adding more books to the library and giving them opportunities to improve their proficiency in English as an extracurricular organization such as English club.

Lastly, this research is designed in a quantitative research. It is expected that other researchers can conduct further research related to this study using qualitative method in order to explore more about the teaching learning process using Fishbone Diagram and teacherstudents perceptions through class observations, interviews and questionnaire distributions. Moreover, since this research makes use only two classes from a school as the research samples, further research is expected to use bigger samples from a bigger population to make the results more reliable.

\section{REFERENCES}

[1] Kurikulum 2013, (2006) Kompetensi Inti dan Kompetensi Dasar Bahasa Inggris Umum SMA/MA/SMK/MAK. Jakarta: Kementrian Pendidikan dan Kebudayaan, p. 5.

[2] Omachonu K. V., \& Rose K. J., (2005) Principles of Total Quality: Third Edition. Washington: CRC Press, p. 265.

[3] Amer, M., , (2013) The Effect of Explicit Instruction in Expository Text Structure on the Writing Performance of Arab EFL University Students. Algeria: The Islamic University of Gaza: Arab World English Journal, vol. 4, no. 1, p. 226.

[4] Moss, B., (2004) Teaching Expository Text Structures through Information Trade Book Retellings. San Diego: International Reading Association, vol.57, no. 8, p. 712.

[5] Tham D, (2013) Expository Ureca: Model Expository Essays for Todays' Secondary School Students. Singapore: Marshall Cavendish Editions, p. 17. 
[6] Martin, J. R., \& Rose, D., (2007) Working with Discourse: Meaning Beyond the Clause. London: Continuum, p. 12.

[7] Haven, K., (2004) Get It Write: Creating Lifelong Writers, from Expository to Narrative. Portsmouth: Teacher Ideas Press, p. 215.

[8] Bashir, M., (2014) Bahasa Inggris. Jakarta: The Ministry of Education and Culture, pp. 113-114.

[9] Omachonu K. V., \& Rose K. J., (2005) Principles of Total Quality: Third Edition. Washington: CRC Press, p. 262.

[10] Dale, B. G., (2003) Managing Quality. Oxford: Blackwell Publishing, p. 327.

[11] Omachonu K. V., \& Rose K. J., (2005) Principles of Total Quality: Third Edition. Washington: CRC Press, pp. 262-263.

[12] Andersen, B., \& Fagerhaug, T., (2006) Root Cause Analysis: Simplified Tools and Techniques. Milwaukee: ASQ Quality Press, p. 119.

[13] Weigle, S. C., (2002) Assessing Writing. Cambridge: Cambridge University Press, p. 116.

[14] Muijs, D., (2004) Doing Quantitative Research in Education with SPSS. London: Sage Publications Ltd, p. 136.

[15] Cohen L, Manion, L., \& Morrison, K., (2007) Research Methods in Education $6^{\text {th }}$ Edition. London and New York: Routledge, p. 521.

[16] Buzan T., (2006) The Buzan Study Skills Handbook. London: BBC Active, p. 114.

[17] Nadell J., Langan J., \& Comodromos A. E., (2007) The Longman Writer: Rhetoric, Reader, Research Guide, and Handbook. New York: Person Education, p. 28. 